\title{
Stabilization/Solidification Treatment of Cadmium-Bearing-Residue with Magnesium Slag
}

\author{
Yujie Chen', Fenglan Han², Yanjie Liang1,3, Ning Peng ${ }^{3,4}$, Bing Peng1,3, \\ Hui Liu ${ }^{1,3 *}$, Zhongbing Wang ${ }^{1}$, Zongwen Zhao ${ }^{1}$ \\ ${ }^{1}$ School of Metallurgy and Environment, Central South University, Changsha, Hunan, China \\ ${ }^{2}$ School of Materials Science and Engineering, Beifang Uinversity of Nationalities, Yinchuan, Ningxia, China \\ ${ }^{3}$ Chinese National Engineering Research Center for Control and Treatment of Heavy Metal Pollution, \\ Changsha, Hunan, China \\ ${ }^{4}$ School of Material Science and Engineering, Central South University, Changsha, Hunan, China
}

Received: 2 September 2018

Accepted: 21 November 2018

\begin{abstract}
Stabilizing/Solidifying cadmium in residue is a great challenge to the treatment of solid waste. In this work, a new stabilization process was proposed to dispose of simulated cadmium-bearing-residue (CBR) by using magnesium slag of the same high-hydration and gelling properties as a binder. A sharp decline in cadmium leaching contraction from $1415 \mathrm{mg} \cdot \mathrm{L}^{-1}$ to less than $1 \mathrm{mg} \cdot \mathrm{L}^{-1}$ was obtained in this new process. The XRD, FT-IR and XPS results indicated it was hydration products and silicates produced by magnesium slag that could promote cadmium $(\mathrm{Cd})$ to take place of calcium $(\mathrm{Ca})$ and immobilize cadmium in the residue. The European Community Bureau of Reference (BCR) experiment also discovered that more reducible, oxidizable and residual fraction in favour of restrained environmental availability was produced in the process.
\end{abstract}

Keywords: stabilization/solidification; magnesium slag; cadmium; leaching test

\section{Introduction}

Cadmium-containing industrial and residual wastes are one of big problems in the environment [1-3]. Numerous treatment methods, such as the stabilization/ solidification $(\mathrm{S} / \mathrm{S})$ process, have been developed to prevent cadmium pollution $[4,5]$. S/S has been widely used because of the short processing time, wide

*e-mail: 625477897@qq.com

**e-mail: liuhuicsu@163.com application scope, simple operation, economic and remarkable solidification effect [6]. Binder is the key to the $\mathrm{S} / \mathrm{S}$ process. Many binders like cement, smelting slag, modified clays and geopolymer were extensively studied and applied into practice [7-9]. It is still important to discover a new binder in large scale according to the background of enterprise and the location.

Magnesium slag is a sub-product generated in production of the metallic magnesium. At the present level of advanced enterprises, magnesium slag of $5-6 \mathrm{~kg}$ is generated from the production of $1 \mathrm{~kg}$ magnesium [10]. Many scholars have studied the 
properties and applications of magnesium slag. According to the composition analysis, the magnesium slag, mainly composed of $\mathrm{Ca}_{2} \mathrm{SiO}_{4}$, is rich in $\mathrm{Ca}, \mathrm{Mg}$, $\mathrm{Si}$ and other elements [11]. Yao et al. [12] pointed out that the magnesium slag had a high hydration activity to generate calcium silicate hydrate gel (C-S-H) after hydration. Additionally, a small amount of the magnesium slag, of course, is recycled for production of cement, wall materials and desulfurizer, etc. [13, 14]. Such properties of magnesium slag indicate the potential to be a good binder for Cd-containing solid waste.

Herein, for the first time, magnesium slag was used to treat cadmium-bearing residue. The $\mathrm{S} / \mathrm{S}$ process was introduced and the related mechanisms were discussed. This new application can digest large amounts of magnesium slag. At the same time, the present work may open a new door to in-depth exploitation of magnesium slag to reduce pollution, protect the environment and achieve the purpose of comprehensive utilization of resources through recovering the wastes by wastes.

\section{Materials and Methods}

\section{Materials}

The waste acid residue used in this work was collected from a $\mathrm{Pb} / \mathrm{Zn}$ smelter in southern China. The waste acid residue was generated during the treatment of flue gas using a lime-neutralization process. The waste acid residue sample was dried in an oven at $105^{\circ} \mathrm{C}$ for $24 \mathrm{~h}$ and then sieved to less than $125 \mu \mathrm{m}$ in size [14]. The magnesium slag was provided by a magnesium smelter in northwestern China. The magnesium slag samples were crushed and sieved to less than $125 \mu \mathrm{m}$ in size [14]. The cadmium-bearingresidue (CBR) was simulated by dissolving various mass ratios of cadmium nitrate solutions in waste acid residue without drying.

\section{Experimental Process}

In order to study the $\mathrm{S} / \mathrm{S}$ ability of magnesium slag, CBR were mixed with magnesium slag at various mass ratios varying from 100:0 to $20: 80$, respectively.
The mass ratio of $\mathrm{m}(\mathrm{Cd}): \mathrm{m}$ (mixtures) varied from 0:100 to 4:96. The liquid-to-solid mass ratios of all mixtures were fixed at 0.5. Sample preparation was presented as follows: cadmium solutions of various concentrations were configured by dissolving different amounts of cadmium nitrate in the distilled water. The waste acid residue was added into the solutions and stirred adequately to obtain the CBR. Then the magnesium slag was mixed into the wet CBR. All the mixtures were blended sufficiently to ensure the homogeneity followed by drying in an oven at $105^{\circ} \mathrm{C}$. Finally, the sample was crushed into fine powder for subsequent study. The sample preparation process and final sample image are shown in Fig. 1. Based on the chemical properties of magnesium slag, the stability of cadmium in the CBR was investigated.

\section{Leaching Test}

In this work, the leachability of cadmium as an important parameter was studied through the leaching toxicity test. The leaching toxicity test was performed based on the HJ/T299-2007 standard method (HJ) [15], solid waste-extraction procedure for leaching toxicity-sulphuric acid and nitric acid method. The HJ leaching test was used to simulate the leaching of contaminated materials by acid leachates and would reflect the process of harmful component release under specified acid rain conditions.

Each experiment was conducted in triplicate and the average results were presented in this paper to minimize random errors and ensure reproducibility. And the concentrations of the heavy metals were determined by chemical analysis methods (ICP-AES and AFS-9130) [16].

\section{Structure Analysis}

The crystallographic composition of the samples was identified by a D/Max $2500 \mathrm{VB}+18 \mathrm{KW}$ X-ray diffractometer (XRD) using $\mathrm{Cu}(40 \mathrm{kV}, 300 \mathrm{~mA})$ radiation with the steps of $0.02^{\circ}$ at $10^{\circ} \cdot \mathrm{min}^{-1}$ in $2 \theta$ ranging from $10^{\circ}$ to $80^{\circ}$. The samples were ground into fine powder for measurement.

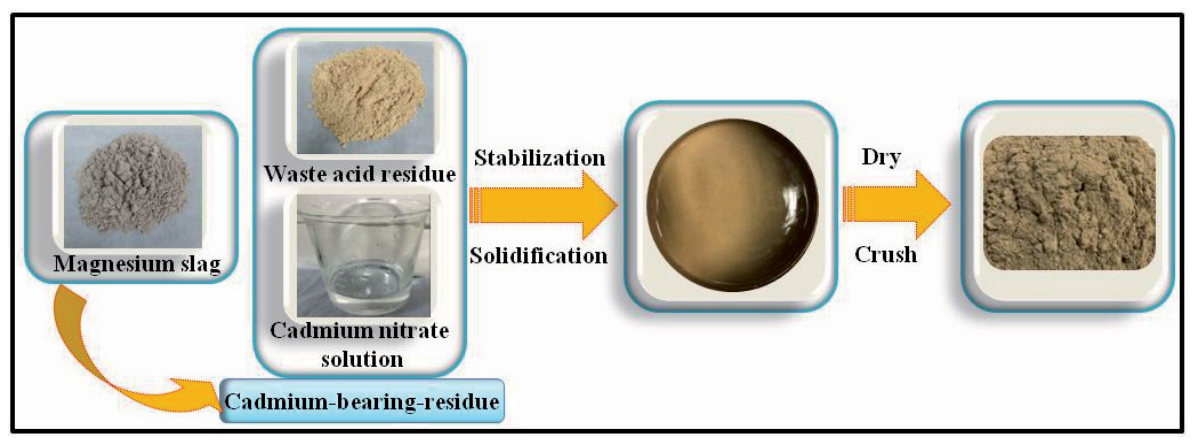

Fig. 1. Schematic illustration of sample preparation. 
Element compositions of the samples were performed on a Japan Science ZSX100e X-ray fluorescence (XRF) spectrometer using $\mathrm{Rh}$ anode radiation and standard slit at $36.5^{\circ} \mathrm{C}$. The specific experimental procedures were according to the study of Ke et al. [17].

The Fourier transform infrared spectroscopy (FTIR) spectra were carried out with a Nicolet IS10 instrument in $\mathrm{KBr}$ pellets (range 400-4000 $\mathrm{cm}^{-1}$ with 4 $\mathrm{cm}^{-1}$ resolution). The samples were prepared using the standard $\mathrm{KBr}$ pellet method. The spectrum of pure $\mathrm{KBr}$ was subtracted from each glass spectrum to correct for the background.

X-ray photoelectron spectroscopy (XPS) experiments were performed with a Thermo Scientific ESCALAB 250Xi using an Al Ka X-ray source (1486.6 eV). To compensate for the charging effects, all spectra were calibrated with graphitic carbon as the reference at the binding energy (BE) of $284.8 \mathrm{eV}$.

\section{Chemical Speciation Analyses of Cadmium}

The adopted sequential extraction test was improved over the sequential extraction procedure proposed by the European Community Bureau of Reference (BCR) based on the Tessier analysis method [18]. Besides soils and sediments, the three-stage BCR has also been applied to evaluate the environmental availability of heavy metals in mine tailings [19] and smelting slag [20, 21]. To explore the chemical speciation and the stability of heavy metals, the CBR containing $4 \mathrm{wt} \% \mathrm{Cd}$ before and after disposing of $40 \mathrm{wt} \%$ magnesium slag were subjected to modified BCR analyses according a study of Li et al. [22].

The chemical speciation of cadmium is divided into four categories: (F1) acid-soluble fraction; (F2) reducible fraction; (F3) oxidizable fraction; and (F4) residual fraction, which got four extracts. The cadmium of all extracts were determined by ICP-AES. All extractions were performed in triplicate and the average values were reported.

\section{Results and Discussion}

\section{Characterization of Waste Acid Residue and Magnesium Slag}

The XRD pattern (Fig. 2a) shows that calcium sulfate dihydrate $\left[\mathrm{CaSO}_{4} \cdot 2 \mathrm{H}_{2} \mathrm{O}\right]$ is the main compound in the waste acid residue. The elemental composition was determined by XRF. The contents of the main elements and some heavy metals in the waste acid residue are presented in Table 1 . Ca and $\mathrm{S}$ are the main element compositions of waste acid residue. The CBR was simulated by waste acid residue. Accordingly, the CBR could be considered as a high calcium sulfatebased slag.

In Fig. 2b, the XRD pattern shows that larnite $\left[\mathrm{Ca}_{2} \mathrm{SiO}_{4}\right]$ and bredigite $\left[\mathrm{Ca}_{14} \mathrm{Mg}_{2}\left(\mathrm{SiO}_{4}\right)_{8}\right]$ are the main
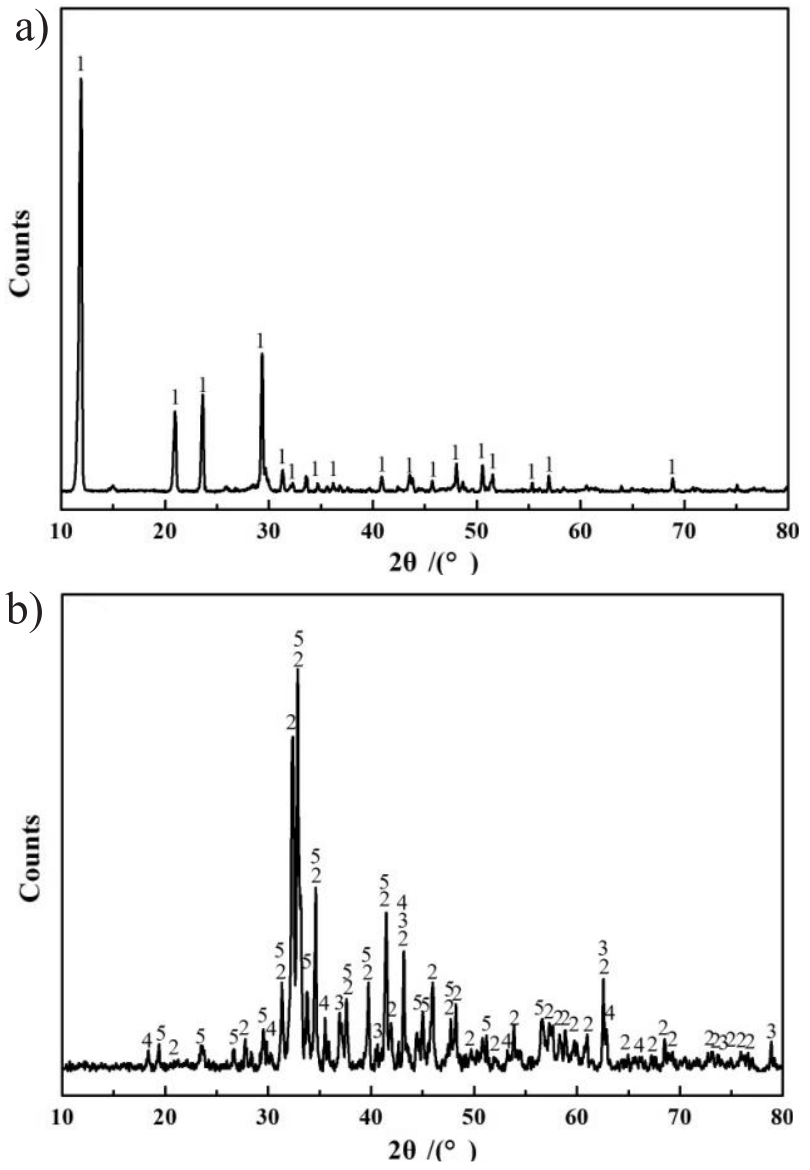

Fig. 2. XRD patterns of the waste acid residue a) and magnesium slag b). $1, \mathrm{CaSO}_{4} \cdot 2 \mathrm{H}_{2} \mathrm{O}(\mathrm{PDF} \# 76-1746)$; 2, $\mathrm{Ca}_{2} \mathrm{SiO}_{4}(\mathrm{PDF} \# 73-2091) ; 3, \mathrm{MgO}(\mathrm{PDF} \# 65-0476) ; 4, \mathrm{MgFe}_{2} \mathrm{O}_{4}$ (PDF\#73-1960); 5, $\mathrm{Ca}_{14} \mathrm{Mg}_{2}\left(\mathrm{SiO}_{4}\right)_{8}(\mathrm{PDF} \# 36-0399)$.

components in the magnesium slag. The elemental composition of the magnesium slag is presented in Table 1. The heavy metals in magnesium slag are all less than $0.05 \%$. And $\mathrm{Ca}, \mathrm{Si}$ and $\mathrm{Mg}$ are the main elements in the magnesium slag, accounting for approximately $76.09 \%$. Therefore, the magnesium slag could be considered a $\mathrm{Ca}-\mathrm{Mg}-\mathrm{Si}$-based material.

\section{Stability Evaluation of Heavy Metals}

Chinese identification for extraction toxicity, GB5085.3-2007 [16], has been used to identify whether general solid wastes and recycled products conform to hazardous waste standards, which stipulates that the concentration of $\mathrm{Cd}, \mathrm{Cr}, \mathrm{Cu}$ and $\mathrm{Zn}$ in the extractions should not exceed $1 \mathrm{mg} \cdot \mathrm{L}^{-1}, 15 \mathrm{mg} \cdot \mathrm{L}^{-1}, 100 \mathrm{mg} \cdot \mathrm{L}^{-1}$ and $100 \mathrm{mg} \cdot \mathrm{L}^{-1}$, respectively. The $\mathrm{CBR}$, in which the contents of $\mathrm{Cd}$ changed from $0 \mathrm{wt} \%$ to $4 \mathrm{wt} \%$, were solidified by different mass ratios of magnesium slag (raging from $0 \mathrm{wt} \%$ to $80 \mathrm{wt} \%$ ). And the leaching toxicity of CBR, disposing with magnesium slag and obtained by the HJ leaching test, were presented in Fig. 3.

In this study, the leaching concentration of $\mathrm{Cd}$ is used as an indicator of immobilization performance. 
Table 1. Elemental analysis of the waste acid residue and the magnesium slag.

\begin{tabular}{|c|c|c|c|c|c|c|c|c|c|c|c|c|c|c|}
\hline & \multicolumn{10}{|c|}{ Elements composition (\%) } \\
\hline & $\mathrm{Ca}$ & $\mathrm{S}$ & $\mathrm{Si}$ & $\mathrm{Fe}$ & $\mathrm{Mg}$ & $\mathrm{Al}$ & $\mathrm{Ti}$ & $\mathrm{Cr}$ & $\mathrm{Mn}$ & $\mathrm{Co}$ & $\mathrm{Ni}$ & $\mathrm{Cu}$ & $\mathrm{Zn}$ & $\mathrm{As}$ \\
\hline Waste acid residue & 37.87 & 14.90 & 1.43 & 5.30 & 0.11 & 0.62 & 0.043 & 0.006 & 0.0487 & - & 0.0006 & 0.023 & 1.38 & 0.17 \\
\hline Magnesium slag & 53.03 & - & 15.81 & 3.58 & 7.25 & 0.77 & 0.025 & 0.01 & 0.0446 & 0.0004 & 0.01 & 0.002 & - & - \\
\hline
\end{tabular}

Fig. 3 shows that the concentration of $\mathrm{Cd}$ in the extraction of $\mathrm{CBR}$ without handling of $\mathrm{S} / \mathrm{S}$ was higher than in the extractions of solidifying by magnesium slag.

Without stabilization by magnesium slag, the concentration of $\mathrm{Cd}$ in the extraction was up to $1.85 \mathrm{mg} \cdot \mathrm{L}^{-1}$ when the content of $\mathrm{Cd}$ in $\mathrm{CBR}$ was $0.5 \mathrm{wt} \%$, which has already exceeded the $\mathrm{Cd}$ concentrations in the standards $\left(1 \mathrm{mg} \cdot \mathrm{L}^{-1}\right)$. Furthermore, the concentration of $\mathrm{Cd}$ in leaching solution was increased with the content of Cd increase. Particularly, when the $\mathrm{Cd}$ content in $\mathrm{CBR}$ was $4 \mathrm{wt} \%$, the concentration of $\mathrm{Cd}$ in the extraction increased to $1415 \mathrm{mg} \cdot \mathrm{L}^{-1}$. However, after stabilization by magnesium slag, $\mathrm{Cd}$ in the CBR is not easy to be leached out, which is in accordance with the previous research [23].

Meanwhile, the concentrations of $\mathrm{Cr}$ (Fig. 2b), $\mathrm{Cu}$ (Fig. 2c) and Zn (Fig. 2d) are all below the standard values, respectively. Both leaching experiments show that magnesium slag could stabilize/solidify $\mathrm{Cd}$ in the CBR well.
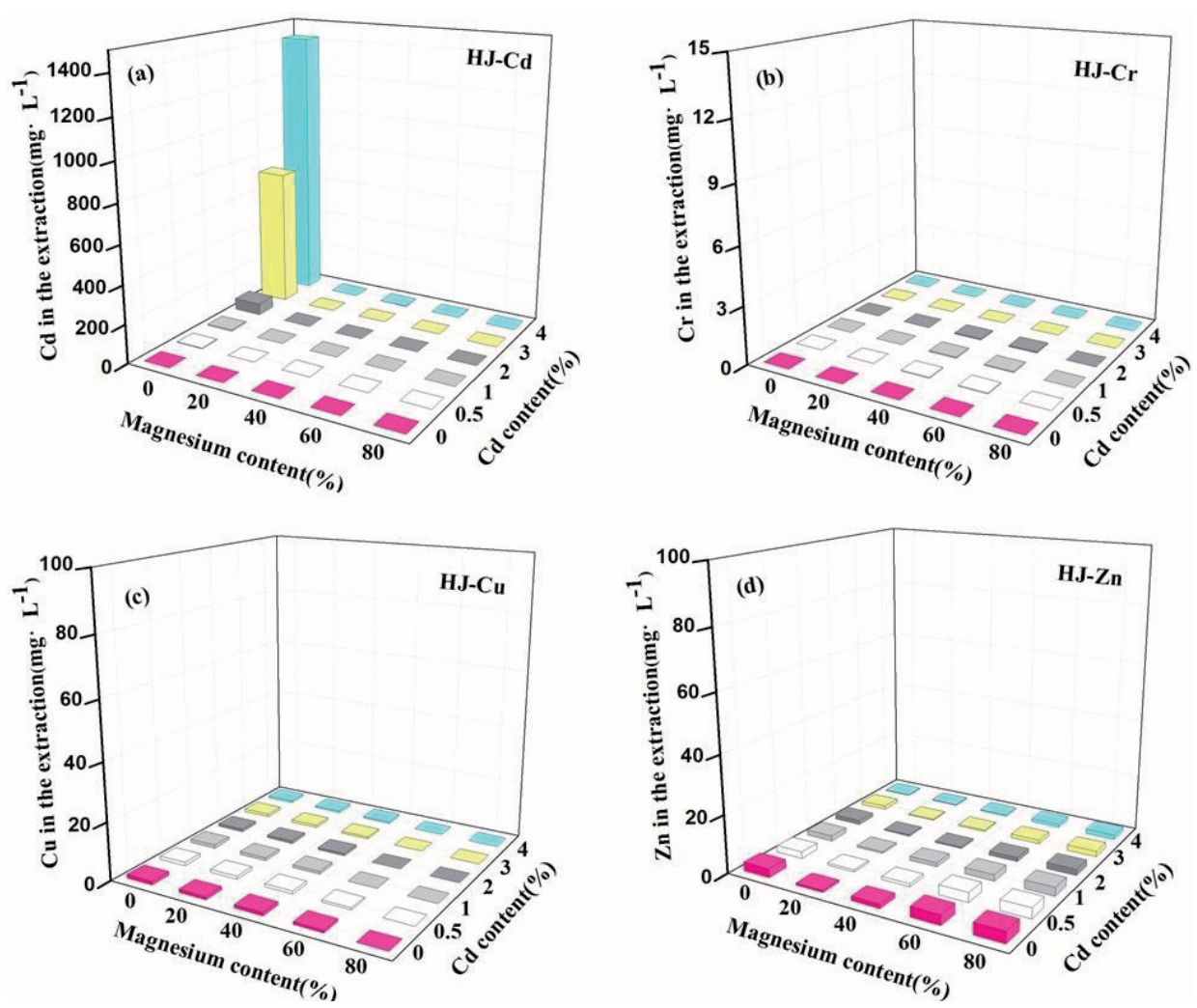

Fig. 3. Metal concentrations in the HJ extractions.

\section{Solidification/Stabilization Characteristics of Magnesium Slag}

\section{X-ray Diffraction Analysis}

As shown in Fig. 2b), the main phase of magnesium slag is $\mathrm{Ca}_{2} \mathrm{SiO}_{4}$, which leads to the decrease of $\mathrm{CaSO}_{4} \cdot \mathrm{nH}_{2} \mathrm{O}$ and the increase of $\mathrm{Ca}_{2} \mathrm{SiO}_{4}$ in the CBR disposing of magnesium slag. After disposing of magnesium slag, the phases in the CBR become complex. As depicted in Fig. 4, the C-S-H gel was formed after hydration, which has high specific surface energy and ion exchange capacity that could remove heavy metal ions by adsorption, symbiosis, ion exchange and other ways of solidification [12]. Many efforts have been devoted to studying the immobilization of $\mathrm{Cd}$ by the C-S-H structure, i.e., M. P. et al. [24] have found that up to $30 \mathrm{wt} \%$ of $\mathrm{Ca}$ in $\mathrm{C}-\mathrm{S}-\mathrm{H}$ can be replaced by $\mathrm{Cd}$, resulting in an increase in the stability of $\mathrm{Cd}$.

Meanwhile, with the increase of magnesium slag stabilizing the $\mathrm{CBR}, \mathrm{Mg}$ could take part in two reactions. 
On the one hand, the $\mathrm{Mg}$ may react with $\mathrm{Ca}_{2} \mathrm{SiO}_{4}, \mathrm{Al}_{2} \mathrm{O}_{3}$ and $\mathrm{CaO}$ in the $\mathrm{CBR}$, forming $\mathrm{Ca}_{54} \mathrm{MgAl}_{2} \mathrm{Si}_{16} \mathrm{O}_{90}[25$, 26] and $\mathrm{Mg}_{2} \mathrm{Al}_{4} \mathrm{Si}_{5} \mathrm{O}_{18}$. The appearance of the crystal, $\mathrm{Ca}_{54} \mathrm{MgAl}_{2} \mathrm{Sil}_{6} \mathrm{O}_{90}$, was corroborated with Shui et al. [27], who reported that alite peaks ceased in fly ash and were slowly replaced by $\mathrm{Ca}_{54} \mathrm{MgAl}_{2} \mathrm{Si}_{16} \mathrm{O}_{90}$ (flue gas desulfurater) after reactions. $\mathrm{Mg}_{2} \mathrm{Al}_{4} \mathrm{Si}_{5} \mathrm{O}_{18}$ can also be written as cordierite $\left[\mathrm{Mg}_{2} \mathrm{Al}_{3}\left(\mathrm{AlSi}_{5} \mathrm{O}_{18}\right)\right]$, in which one of $\mathrm{Si}^{4+}$ is replaced by $\mathrm{Al}^{3+}$, which belongs to the hexagonal system. The basic structural unit of $\mathrm{Mg}_{2} \mathrm{Al}_{3}\left(\mathrm{AlSi}_{5} \mathrm{O}_{18}\right)$ is an isolated six-node ring [28]. And a huge channel is formed within the six segments of the ring superimposed, in which the $\mathrm{Cd}^{2+}$ could be stored. This can make cadmium in the CBR stable and not easily leached out.

On the other hand, the $\mathrm{Mg}$ can be hydrated to produce $\mathrm{Mg}_{6} \mathrm{Al}_{2}(\mathrm{OH})_{18} \cdot 4 \mathrm{H}_{2} \mathrm{O}$, commonly accepted as layered double hydroxides, which is usually observed in natural soil and hydration product obtained from the heavy metal $\mathrm{S} / \mathrm{S}$ by cement concrete [29, 30]. Furthermore, most divalent and trivalent metal ions can be wrapped in the layered double hydroxide materials, including $\mathrm{Cd}^{2+}$ [31]. In addition, the $\mathrm{Mg}_{6} \mathrm{Al}_{2}(\mathrm{OH})_{18} \cdot 4 \mathrm{H}_{2} \mathrm{O}$ together with $\mathrm{KCa}_{2} \mathrm{AlSi}_{7} \mathrm{O}_{17}(\mathrm{OH})_{2} \cdot 6 \mathrm{H}_{2} \mathrm{O}$ could increase the $\mathrm{pH}$ value in the $\mathrm{CBR}$ system. The high $\mathrm{pH}$ value environment is conducive to the adsorption of $\mathrm{Cd}$ and could transform $\mathrm{Cd}$ into oxidizable and residual states [32].

In summary, the alkalinity of the system can be improved by solidifying $\mathrm{CBR}$ with magnesium slag. Furthermore, the hydration products (C-S-H, $\mathrm{Mg}_{6} \mathrm{Al}_{2}(\mathrm{OH})_{18} \cdot 4 \mathrm{H}_{2} \mathrm{O}$ and $\left.\mathrm{KCa}_{2} \mathrm{AlSi}_{7} \mathrm{O}_{17}(\mathrm{OH})_{2} \cdot 6 \mathrm{H}_{2} \mathrm{O}\right)$ and silicates $\left(\mathrm{Ca}_{54} \mathrm{MgAl}_{2} \mathrm{Si}_{16} \mathrm{O}_{90}\right.$ and $\left.\mathrm{Mg}_{2} \mathrm{Al}_{4} \mathrm{Si}_{5} \mathrm{O}_{18}\right)$ can be produced. Thus the cadmium in the CBR system can be solidified/stabilized.

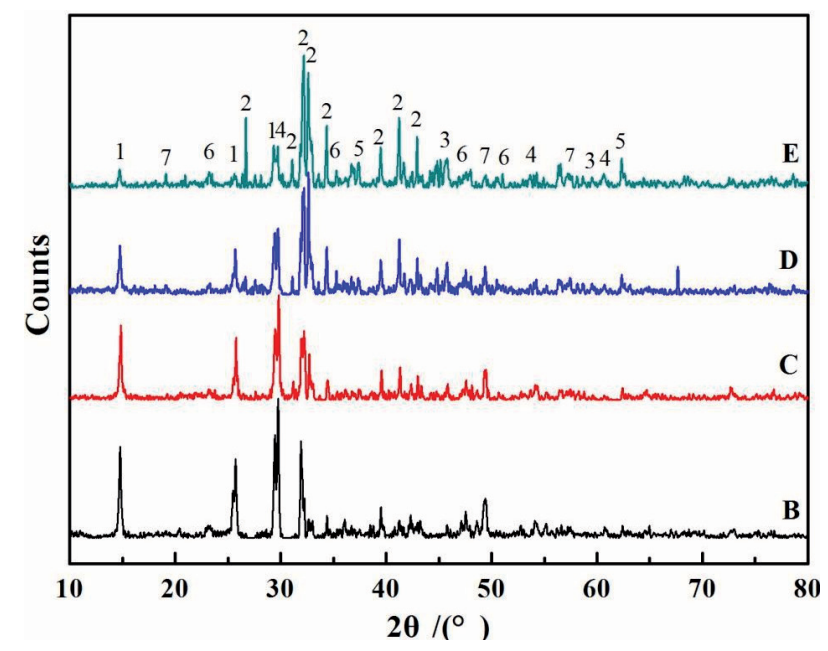

Fig. 4. XRD patterns of CBR (4 wt $\% \mathrm{Cd}$ ) disposing of $20 \mathrm{wt} \%$ (B), $40 \mathrm{wt} \%$ (C), $60 \mathrm{wt} \%$ (D), and $80 \mathrm{wt} \%$ (E) magnesium slag. $1, \mathrm{CaSO}_{4} \cdot 0.5 \mathrm{H}_{2} \mathrm{O}$ (PDF\#81-1848); 2,C-S-H(PDF\#89-6458); 3,Ca $\left.{ }_{54} \mathrm{MgAl}_{2} \mathrm{Si}_{16} \mathrm{O}_{90}(\mathrm{PDF} \# 13-0272) ; \quad 4, \mathrm{KCa}_{2} \mathrm{AlSi}_{7} \mathrm{O}_{17}(\mathrm{OH})\right)_{2} \cdot 6 \mathrm{H}_{2} \mathrm{O}(\mathrm{P}$ DF\#53-0969); 5, MgO(PDF\#65-0476); 6, $\mathrm{Mg}_{6} \mathrm{Al}_{2}(\mathrm{OH})_{18} \cdot 4 \mathrm{H}_{2} \mathrm{O}(\mathrm{P}$ DF\#38-0478); 7, $\mathrm{Mg}_{2} \mathrm{Al}_{4} \mathrm{Si}_{5} \mathrm{O}_{18}$ (PDF\#14-0249)

\section{Fourier Transform Infrared Spectroscopic Analysis}

The CBR containing 4 wt $\%$ Cd without magnesium slag and disposing of $20 \mathrm{wt} \%, 40 \mathrm{wt} \%$, $60 \mathrm{wt} \%, 80 \mathrm{wt} \%$ magnesium slag were investigated by the FT-IR spectra (Fig. 5). The bands at $3552 \mathrm{~cm}^{-1}$, $3406 \mathrm{~cm}^{-1}, 1687 \mathrm{~cm}^{-1}, 1622 \mathrm{~cm}^{-1}, 1115 \mathrm{~cm}^{-1}, 663 \mathrm{~cm}^{-1}$, $602 \mathrm{~cm}^{-1}$ and $462 \mathrm{~cm}^{-1}$ in CBR without magnesium slag are attributed to the calcium sulfate dihydrate $\left[\mathrm{CaSO}_{4} \cdot 2 \mathrm{H}_{2} \mathrm{O}\right][33,34]$.

After disposing of magnesium slag, the new band at $3610 \mathrm{~cm}^{-1}$ corresponds to Si-OH-Al stretching vibration of the CBR system [35], which indicates that $\mathrm{KCa}_{2} \mathrm{AlSi}_{7} \mathrm{O}_{17}(\mathrm{OH})_{2} \cdot 6 \mathrm{H}_{2} \mathrm{O}$ is gradually forming. The broad band at $1460-1400 \mathrm{~cm}^{-1}$ is related to the $\mathrm{Mg}-\mathrm{O}$ stretching vibrations and the $\mathrm{Mg}-\mathrm{O}-\mathrm{Mg}$ deformation vibrations [36]. The bands belonging to $\mathrm{M}-\mathrm{OH}(\mathrm{M}=\mathrm{Mg}$ or Al) are present near $1100 \mathrm{~cm}^{-1}$ [37].

The bands at $1145 \mathrm{~cm}^{-1}$ in the spectra of the CBR are attributed to the $\mathrm{Si}-\mathrm{O}-\mathrm{Si}$ asymmetric stretching in tetrahedral [38]. The bands at $1386 \mathrm{~cm}^{-1}$ and $871 \mathrm{~cm}^{-1}$ are assigned to the asymmetric stretching vibrations of Si-O [39], but the bands at $871 \mathrm{~cm}^{-1}$ in the CBR gradually weaken. Moreover, the new bands at $512 \mathrm{~cm}^{-1}$ generate and increase progressively, which supports a new $\mathrm{Si}-\mathrm{O}-\mathrm{T}(\mathrm{T}=\mathrm{Si}$ or $\mathrm{Al})$ band appearing [40]. The changes of the four peaks indicate that the addition of magnesium slag reacts in the CBR system, resulting in the formation of new Si-O-T ( $\mathrm{T}=\mathrm{Si}$ or $\mathrm{Al})$ structure. Comparing these results, it can be inferred that there is $\mathrm{C}-\mathrm{S}-\mathrm{H}$ in the CBR disposing of magnesium slag. In addition, the added magnesium slag will improve the alkalinity of the CBR system, which is conducive to the dissolution of silicon dioxide. Then, the new silicate phases are formed through reactions, such as $\mathrm{Ca}_{54} \mathrm{MgAl}_{2} \mathrm{Si}_{16} \mathrm{O}_{90}$ and $\mathrm{Mg}_{2} \mathrm{Al}_{4} \mathrm{Si}_{5} \mathrm{O}_{18}$. The FT-IR analysis of the CBR system is in agreement with the results of XRD results.

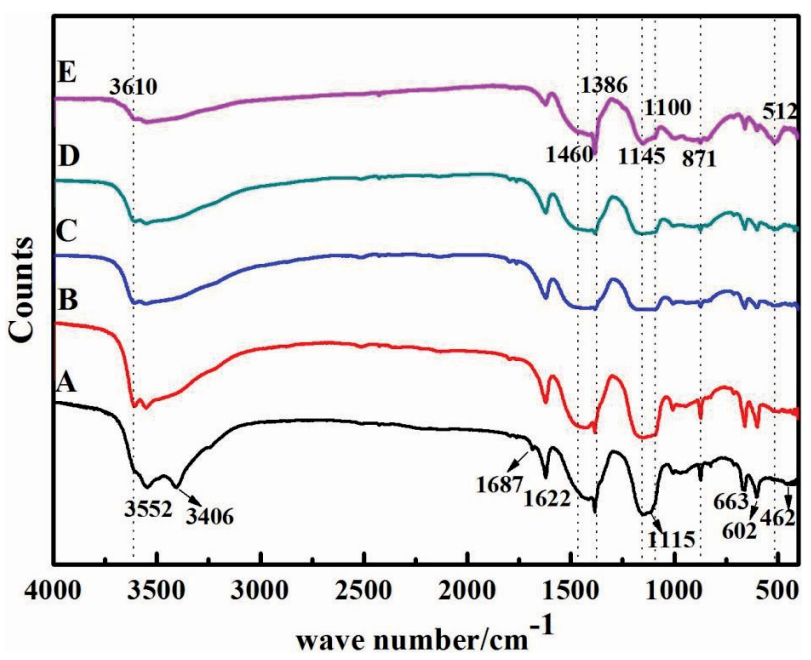

Fig. 5. FT-IR spectra of CBR ( $4 \mathrm{wt} \% \mathrm{Cd}$ ) disposing of $0 \mathrm{wt} \%$ (A), $20 \mathrm{wt} \%$ (B), $40 \mathrm{wt} \%$ (C), $60 \mathrm{wt} \%$ (D) and $80 \mathrm{wt} \%$ (E) magnesium slag. 


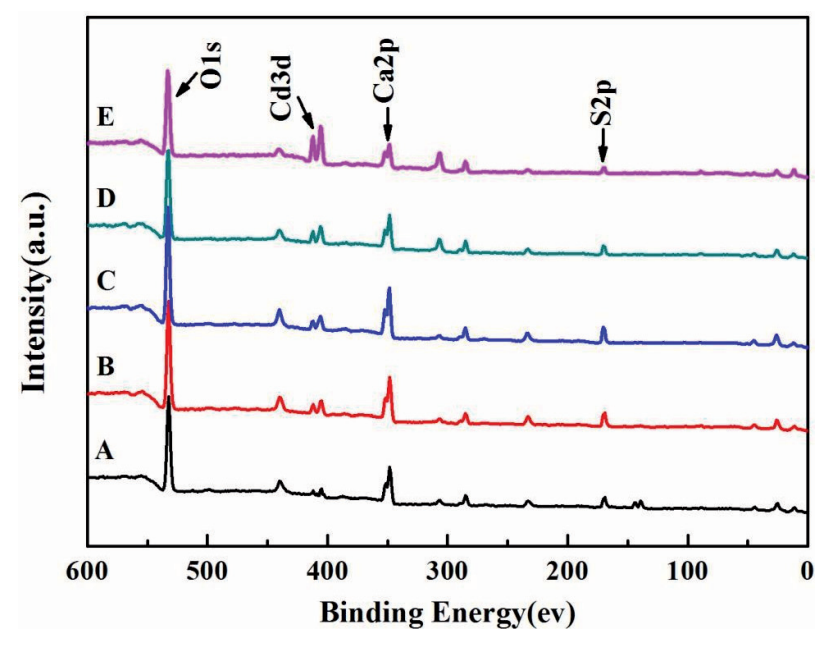

Fig. 6. XPS survey scans of CBR ( $4 \mathrm{wt} \% \mathrm{Cd}$ ) disposing with 0 $\mathrm{wt} \%$ (A), $20 \mathrm{wt} \%$ (B), $40 \mathrm{wt} \%$ (C), $60 \mathrm{wt} \%$ (D) and $80 \mathrm{wt} \%$ (E) magnesium slag.

\section{X-ray Photoelectron Spectroscopic Analysis}

XPS experiments have been conducted to examine the detailed structure information of the CBR. Survey scans of the CBR containing $4 \mathrm{wt} \% \mathrm{Cd}$ disposing of $0 \mathrm{wt} \%$ (A4), $20 \mathrm{wt} \%$ (B4), $40 \mathrm{wt} \%$ (C4), $60 \mathrm{wt} \%$ (D4), and $80 \mathrm{wt} \%$ (E4) magnesium slag are shown in Fig. 6. It can be seen that calcium, oxygen, sulfur and cadmium have been detected in the CBR, which indicates that cadmium has been immobilized into the CBR.

Moreover, it can be observed that a small peak related to cadmium has been detected in the CBR containing $4 \mathrm{wt} \% \mathrm{Cd}$ without magnesium slag. While with the increase of magnesium slag stabilizing the CBR, the intensity of $\mathrm{Cd} 3 \mathrm{~d}$ increases gradually. Meanwhile, the peak intensity concerning calcium decreases. However, the calcium in the magnesium slag is higher than that in the CBR, as shown in Table 1. Comparing this information, it can be speculated that there is a substitution of calcium by cadmium in the CBR disposing of magnesium slag, which was corroborated with M. P. et al. [24]. The same valence state $(+2)$ of cadmium and calcium and the sililarity in ionic radius $\left(0.99\right.$ and $0.97 \AA$ for $\mathrm{Ca}^{2+}$ and $\mathrm{Cd}^{2+}$, respectively [41] ) may promote the replacement of cadmium and calcium. Therefore, the cadmium can form chemical bonds immobilized in the CBR structure and not easily extracted.

\section{Chemical Speciation Analyses of Cadmium}

Cadmium stability in the wastes is a vital factor that should be considered when using slag to immobilize $\mathrm{Cd}$. According to previous studies [42, 43], the cadmium stability is closely related to the cadmium chemical a)

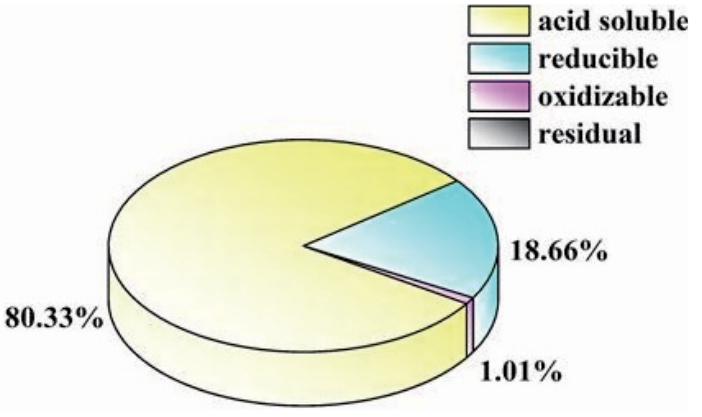

b)

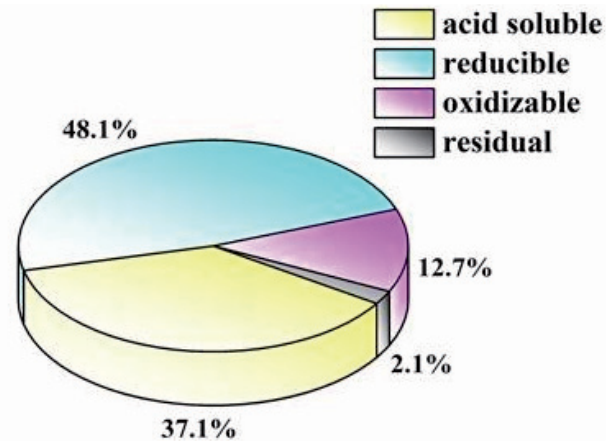

Fig. 7. BCR chemical speciation of $\mathrm{Cd}$ in $\mathrm{CBR}(4 \mathrm{wt} \% \mathrm{Cd})$ before a) and after b) disposing of $40 \mathrm{wt} \%$ magnesium slag.

speciation. Therefore, a BCR experiment has been conducted to test the cadmium chemical speciation in the CBR.

The percentages for acid-soluble, reducible, oxidizable and residual fractions are noted as F1, F2, F3 and F4. According to the extraction method, the F1 value, namely the acid-soluble fraction, is often considered as a highly mobile and bioavaiable fraction. However, F2, F3 and F4 fractions could be regarded as the relative stable forms under the weak acid environment [44].

Of the four fractions studied, $\mathrm{Cd}$ distribution patterns in CBR $(4 \mathrm{wt} \% \mathrm{Cd}$ ) before (Fig. 7a) and after (Fig. 7b) disposing of $40 \mathrm{wt} \%$ magnesium slag are different. Without magnesium slag, $\mathrm{Cd}$ in $\mathrm{CBR}$ was present at the highest relative level in the $\mathrm{F} 1$ faction $(80.3 \%)$, suggesting that the mobility of Cd was strong. While after disposing of magnesium slag, F1 faction was down to $37.1 \%$; correspondingly, F2, F3 and F4 factions increased from $18.79 \%, 1.02 \%, 0 \%$ to $48.1 \%$, $12.7 \%, 2.1 \%$, respectively, resulting in an increase of the other three factions (F2+F3+F4) from $19.67 \%$ to $62.9 \%$ compared to Fig. 3a). This is because the lime and other alkaline substances in the magnesium slag convert the cadmium into F3 and F4, which is in accordance with the previous literature $[32,45]$. As a result, the concentration of $\mathrm{Cd}$ in the extraction was reduced from $1415 \mathrm{mg} \cdot \mathrm{L}^{-1}$ to $0.58 \mathrm{mg} \cdot \mathrm{L}^{-1}$ (Fig. 3a). Therefore, the $\mathrm{Cd}$ chemical speciation implies that the magnesium slag could potentially exchange the mobile faction to the chemically recalcitrant and least factions. 


\section{Conclusions}

In summary, the simulated cadmium-bearingresidue was stabilized/solidified by magnesium slag. The magnesium slag can decrease cadmium leaching concentrations from $1415 \mathrm{mg} \cdot \mathrm{L}^{-1}$ to less than $1 \mathrm{mg} \cdot \mathrm{L}^{-1}$. Meanwhile, $\mathrm{Cr}, \mathrm{Cu}$ and $\mathrm{Zn}$ in the $\mathrm{CBR}$ are also under safety thresholds. The hydration products (C-S-H, $\mathrm{Mg}_{6} \mathrm{Al}_{2}(\mathrm{OH})_{18} \cdot 4 \mathrm{H}_{2} \mathrm{O}$ and $\left.\mathrm{KCa}_{2} \mathrm{AlSi}_{7} \mathrm{O}_{17}(\mathrm{OH})_{2} \cdot 6 \mathrm{H}_{2} \mathrm{O}\right)$ and silicates $\left(\mathrm{Ca}_{54} \mathrm{MgAl}_{2} \mathrm{Si}_{16} \mathrm{O}_{90}\right.$ and $\left.\mathrm{Mg}_{2} \mathrm{Al}_{4} \mathrm{Si}_{5} \mathrm{O}_{18}\right)$ can be produced by magnesium slag because of the high hydration and gelling properties. Furthermore, the addition of magnesium slag could promote the substitution of calcium by cadmium in the CBR, which makes cadmium remain stable. The above improvement properties of magnesium slag could reduce the acidsoluble fraction of cadmium in the cadmium-bearingresidue, resulting in a restrained environmental availability.

This ability of S/S may open the door to in-depth exploitation of magnesium slag to reduce pollution, protect the environment and achieve the purpose of comprehensive utilization of resources through recovering the wastes by wastes. However, more work has to be done to test its impact on long-term landfill so that the approach can be more reliable and effective.

\section{Acknowledgements}

The authors gratefully acknowledge financial support from the Program for the Science and Technology Support Program of Ningxia, China, and the Program for the National Natural Science Foundation of China (51574295).

\section{Conflict of Interest}

The authors declare no conflict of interest.

\section{References}

1. LEI J., PENG B., MIN X.B., LIANG Y.J., YANG Y., CHAI L.Y. Modeling and optimization of lime-based stabilization in high alkaline arsenic-bearing sludges with a central composite design. Environmental Letters, 52 (5), 449, 2017.

2. LIU D.G., MIN X.B., KE Y., CHAI L.Y., LIANG Y.J., LI Y.C., YAO L.W., WANG Z.B. Co-treatment of flotation waste, neutralization sludge, and arsenic-containing gypsum sludge from copper smelting: solidification/ stabilization of arsenic and heavy metals with minimal cement clinker. Environmental Science and Pollution Research, 25, 7600, 2017.

3. YANG Z.H., WU, Z.J., LIAO Y.P., LIAO Q., YANG, W.C., CHAI L.Y. Combination of microbial oxidation and biogenic schwertmannite immobilization: A potential remediation for highly arsenic-contaminated soil. Chemosphere, 181, 1, 2017.
4. CHEN Q.Y., TYRER M., HILLS C.D., YANG X.M., CAREY P. Immobilization of heavy metal in cement-based solidification/stabilization: A review. Waste Management, 29 (1), 390, 2009.

5. YAN X., LI Q.Z., CHAI L.Y., YANG, B.T., WANG, Q.W. Formation of abiological granular sludge-a facile and bioinspired proposal for improving sludge settling performance during heavy metal wastewater treatment. Chemosphere, 113, 36, 2014.

6. YIN C.Y., MAHMUD H.B., SHAABAN M.G. Stabilization/solidification of lead-contaminated soil using cement and rice husk ash. Journal of Hazardous Materials, 137, 1758, 2006.

7. DESOGUS P., MANCA P.P., ORRU G., ZUCCA A. Stabilization-solidification treatment of mine tailings using Portland cement, potassium dihydrogen phosphate and ferric chloride hexahydrate. Minerals Engineering, 45 (5), 47, 2013

8. JANG A., KIM I.S. Solidification and stabilization of $\mathrm{Pb}$, $\mathrm{Zn}, \mathrm{Cd}$ and $\mathrm{Cu}$ in tailing wastes using cement and fly ash. Minerals Engineering, 13 (14), 1659, 2000.

9. LI Y.C., MIN X.B., CHAI L.Y., SHI M.Q., TANG C.J., WANG Q.W., LIANG Y.J., LEI J., LIYANG W.J. Co-treatment of gypsum sludge and $\mathrm{Pb} / \mathrm{Zn}$ smelting slag for the solidification of sludge containing arsenic and heavy metals. Journal of Environmental Management, 181, 756, 2016.

10. YILMAZ S., ÇEKEN K., ALPARSLAN A. Smelting refining magnesium with Pijiang Process combined with production of nonmetallic functional material is an advanced technology of environmental protection type. World Nonferrous Metals, 13 (13), 156, 2006.

11. HAN F.L., WU L.E., GUO S.W., YANG Q.X., DU C.. Fluoride evaporation during thermal treatment of waste slag from $\mathrm{Mg}$ production using Pidgeon process. Advanced Materials Research, 581-582 (1), 1044, 2012.

12. YAO Y., WANG X., YAN B.L., WANG L., LIU C.. The research on heavy metal ions curing and its influence on the cement hydration process. Bulletin of the Chinese Ceramic Society, 31, 1138, 2012.

13. XIA D.H., REN L., CHEN L.Z.. Study of Ca-Mg-S$\mathrm{Si}$ fertilizer produced by magnesium slag. Advanced Materials Research, 347-353, 3166, 2012.

14. CHEN Y.J., HAN F.L., LUO Z. Magnesium slag solidify/ stabilize heavy metal $\mathrm{Cu}$ and $\mathrm{Cd}$ in waste acid residue. Inorganic chemicals industry, 47, 48, 2015.

15. HJ/T299-2007, Solid waste-extraction procedure for leaching toxicity-sulphuric acid \& nitric acid method. 2007, China.

16. GB5085.3-2007, Identification standards for hazardous wastes-Identification for extraction toxicity. 2007, China.

17. KE Y., CHAI L.Y., MIN X.B., TANG C.J., ZHOU B.S., CHEN J., YUAN C.Y. Behavior and effect of calcium during hydrothermal sulfidation and flotation of zinc-calcium-based neutralization sludge. Minerals Engineering, 74 (3), 68, 2015.

18. TESSIER A., CAMPBELL P.G.C., BISSON M. Sequential extraction procedure for the speciation of particulate trace metals. Analytical Chemistry, 51 (7), 844, 1979.

19. ANJU M., BANERJEE D.K. Comparison of two sequential extraction procedures for heavy metal partitioning in mine tailings. Chemosphere, 78 (11), 1393, 2010.

20. XIE X.D., MIN X.B., CHAI L.Y., TANG C.J., LIANG Y.J., LI M., KE Y., CHEN J., WANG Y. Quantitative evaluation of environmental risks of flotation tailings from 
hydrothermal sulfidation-flotation process. Environmental Science \& Pollution Research, 20 (9), 6050, 2013.

21. LU L., LI D.W., ZHU FZ. Study on the morphological analysis of heavy metals of the smelting slag for lead and zinc. Research Journal of Chemistry \& Environment, 15 (2), 164, 2011.

22. LI Y.C., MIN X.B., KE Y., CHAI L.Y., SHI M.Q., TANG C.J., WANG Q.W., LIANG Y.J., LEI J., LIU D.G. Utilization of red mud and $\mathrm{Pb} / \mathrm{Zn}$ smelter waste for the synthesis of a red mud-based cementitious material. Journal of Hazardous Materials, 344, 343, 2018.

23. CHEN Y.J., HAN F.L., LUO Z. Solidification and stabilization of heavy mental $\mathrm{Pb}$ in waste acid residue by magnesium slag. Chinese Journal of Environmental Engineering, 10, 3229, 2016.

24. POMIES M.P., LEQUEUX N., BOCH P.. Speciation of cadmium in cement: Part I. Cd ${ }^{2+}$ uptake by C-S-H. Cement \& Concrete Research, 31 (4), 563, 2001.

25. ZHOU S.Q., LIN Y.M., ZHAO J.J., ZENG S.F., ZHOU J.H. Utilization of the alkaline white mud as cement-based materials for the production of cement. Journal of Civil \& Environmental Engineering, 2 (1), 1, 2012.

26. SAZONOVA N., SKRIPNIKOVA N. Physico-mechanical and physico-chemical properties of synthesized cement based on plasma and wet technologies. Aip Conference, 1698, 55-61, 2016.

27. SHUI A.Z., GONG H., ZENG L.K., WANG H., LIU P.A., CHENG X.S. Preparation of Flue Gas Desulfurater by Mechanochemical Effect. Bulletin of the Chinese Ceramic Society, 27 (1), 202, 2008.

28. GAFT M., REISFELD R., PANCZER G. Modern Luminescence Spectroscopy of Minerals and Materials. Springer Berlin Heidelberg, 2015.

29. ISABELLE M., WILLIAM E.E. STONE, JESUS S., JEAN Y.B., FRANCIS M., CLAUDE H. Retention of Zinc and Chromium Ions by Different Phases of Hydrated Calcium Aluminate: A Solid-State 27Al NMR Study. Journal of Physical Chemistry B, 104 (39), 9230, 2000.

30. VESPA M., DAHN R., GROLIMUD D., WIELAND E., SCHEIDEGGER A.M. Spectroscopic investigation of $\mathrm{Ni}$ speciation in hardened cement paste. Cement \& Concrete Research, 40 (7), 2275, 2006.

31. ZHOU J.Z., WU Y.Y., LIU C., ORPE A., LIU Q., XU Z.P., QIAN G.R., QIAO S.Z. Effective self-purification of polynary metal electroplating wastewaters through formation of layered double hydroxides. Environmental Science \& Technology, 44 (23), 8884, 2010.

32. LIAO M., HUANG C.Y., XIE Z.M. Effect of $\mathrm{pH}$ on transport and transformation of cadmium in soil water system. Actaentiae Circumstantiae, 19, 81, 1999.

33. WANG S.P., XU Y.Z. Fourier transform infrared spectroscopy analysis, $3^{\text {rd }}$ ed.; Chemical Industry Press, Beijing, 2016.
34. WEI Y., LIAO J.C., WANG S.M., LIANG S.W., YU J.Y. The FTIR finger print of gypsum fibrosum. Acta Medica Mediterranea, 32, 607, 2016.

35. JIN F., LI Y.D. A FTIR and TPD examination of the distributive properties of acid sites on ZSM-5 zeolite with pyridine as a probe molecule. Catalysis Today, 145 (1-2), 101, 2009.

36. MIRONYUK I.F., GUNKOV.M., POVAZHNYAK M.O., ZARKO V.I., CHELYADIN V.M., LEBODA R., SKUBISZEWSKA Z.J., JANUSZ W. Magnesia formed on calcination of $\mathrm{Mg}(\mathrm{OH})_{2}$ prepared from natural bischofite. Applied Surface Science, 252 (12), 4071, 2006.

37. ACKERMANN M.N.. Infrared spectra of inorganic and coordination compounds (Nakamoto, Kazuo). WILEY, $1122,1986$.

38. ZHAO, Z.W., CHAI L.Y., LIANG Y.J., MIN X.B., FEI J.C., MA J.J. The vitrification of arsenic-rich residue using iron phosphate glass. Physics and Chemistry of GlassesEuropean Journal of Glass Science and Technology Part B, 58, 109, 2017.

39. AHMARI S., ZHANG L. Utilization of cement kiln dust (CKD) to enhance mine tailings-based geopolymer bricks. Construction \& Building Materials, 40 (3), 1002, 2013.

40. REES C.A., PROVIS J.L., LUKEY G.C., DEVENTER J.S. In situ ATR-FTIR study of the early stages of fly ash geopolymer gel formation. Langmuir the Acs Journal of Surfaces \& Colloids, 23 (17), 9076, 2007.

41. VERBOST P.M., FLIK G., LOCL R.A. Cadmium inhibition of $\mathrm{Ca}^{2+}$ uptake in rainbow trout gills. Am J Physiol, 253 (2), 216, 1987.

42. SASTRE J., HENRNANDEZ E., RODRIGUEZ R., ALCOBE X., VIDAL M., RAURET G. Use of sorption and extraction tests to predict the dynamics of the interaction of trace elements in agricultural soils contaminated by a mine tailing accident. Science of the Total Environment, 329 (1-3), 261, 2004.

43. ZHAO Z.W., SONG Y.X., MIN X.B., LIANG Y.J., CHAI L.Y., SHI M.Q. XPS and FTIR studies of sodium arsenate vitrification by cullet. Journal of Non-Crystalline Solids, 452, 238, 2016.

44. LIANG Y.J., MIN X.B., CHAI L.Y., WANG, M., LIYANG, W.J., PAN Q.L., ORIDO M. Stabilization of arsenic sludge with mechanochemically modified zero valent iron. Chemosphere, 168, 1142, 2016.

45. YANG S.L., ZHOU D.Q., YU H.Y., WWI R., PAN B. Distribution and speciation of metals $(\mathrm{Cu}, \mathrm{Zn}, \mathrm{Cd}$, and $\mathrm{Pb})$ in agricultural and non-agricultural soils near a stream upriver from the Pearl River, China. Environmental Pollution, 177 (4), 64, 2013.

46. ZHONGBING W., ZONGWEN Z., LIFENG Z., FANSONG L., BING P., LIYUAN C., DACHUN L., DEGANG L., TIANYU W., HUI L., YANJIE L.. Formation mechanism of zinc-doped fayalite $\left(\mathrm{Fe}_{2}-\mathrm{xZnxSiO}{ }_{4}\right)$ slag during copper smelting. Journal of Hazardous Materials, 364 (15), 488, 2019. 